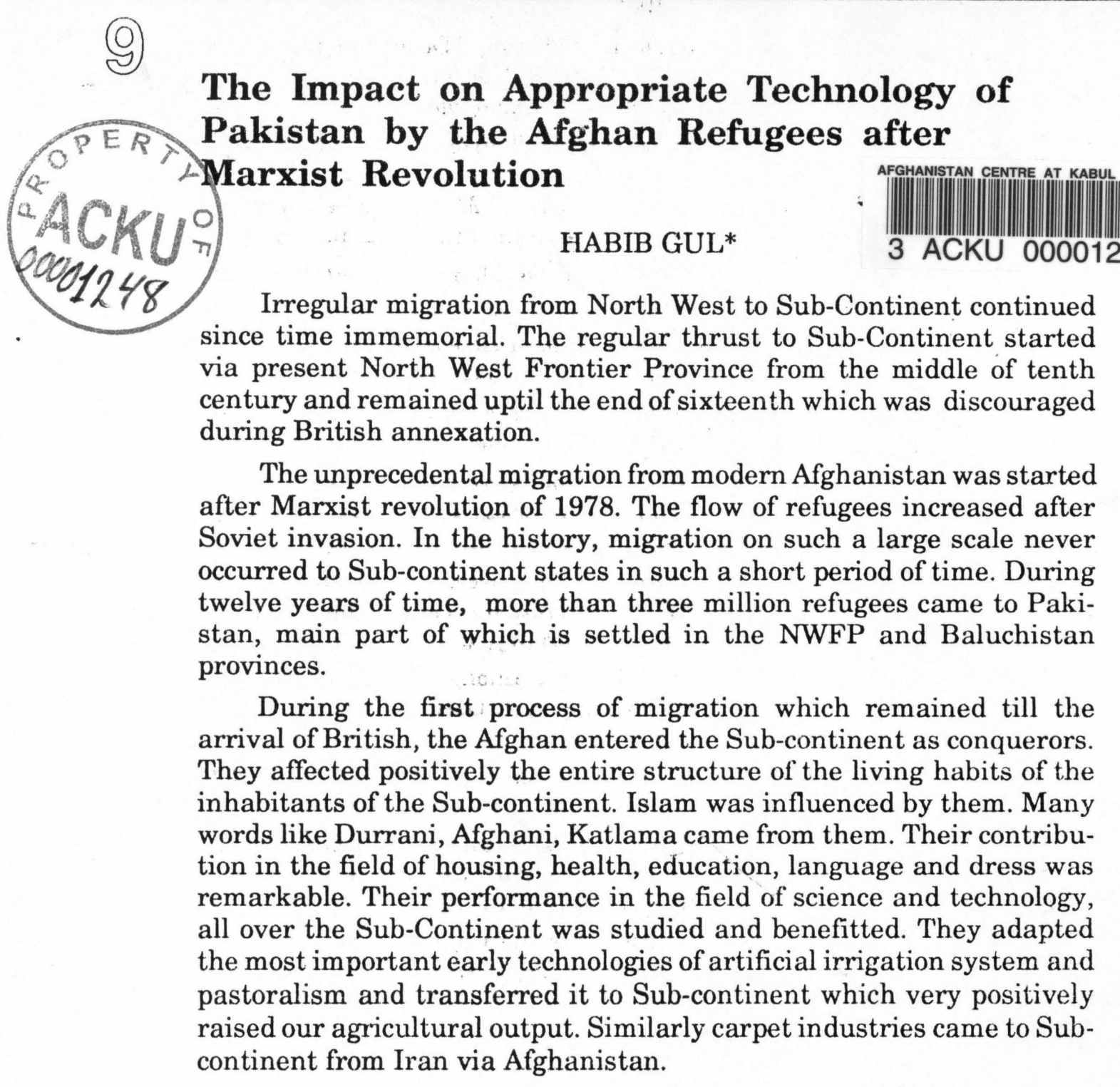

Now we come to the second process of the Afghans migration to Pakistan which is forceful and to some extent, compulsory. After Marxist revolution of 1978, they came to Pakistan, a part of Sub-continent. They left their business, land property and even their decorated homes

*Deputy Director, PCAT St. No. 8 Gharibabad P.O. Tehkal Bala, Peshawar. 
gloomy and in subdued condition. Due to their backwardness in the field of education, science and technology and hesitating in changing their lives with the changing atmosphere of the post industrial revolution, they were compelled to live in traditional society of Afghanistan. In such as atmosphere the people refuse in adapting technology, hating the technical personnel by calling them Chamyar (cobler) Jullah ah (weaver) and other bad names in the society. The priests, religious leaders, feudals occupy predominant roles in the states politics, trade, commerce, industries and in government positions. In these circumstances, after Russian invasion, the migrants from Afghanistan are being supported by Refugees Care Programme which is a million dollar a day, half of which is being donated by the foreign agencies and governments while the remaining is met by the Government of Pakistan.

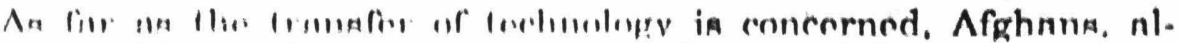

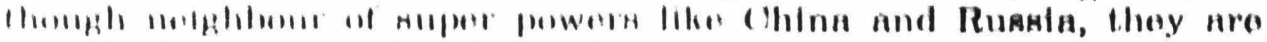
unskilled, uneducated have trend towards trade, commerce, transport and property dealing. The poor refugees living in the tentage villages near the surroundings of cities are earning daily wages by providing their labour in construction industries, baking of bread, running hotels and dealing in second hand clothes. They did not transfer any sort of technology to the hosts. In fact, Pakistan made a great deal of progress and development in sophisticated as well as in intermediate technologies, feasible for its needs, though less than the required pace, yet more in quantity and quality than the Afghanistan. Afghan technology in no case is superior to Pakistanis technologies. The donor agencies took interest in the provision and extension of the existing technologies rather than importing and transferring in favour of refugees and the areas affecting by the refugees due to over grazing, desertification etc. As the content of this essay is the impact on appropriate technology in Pakistani society with arrival of Afghan refugees, hence only a few sectors of the technology relating to employment, income generating, forestation and energy saving is briefed rather than the sophisticated technologies of Kalashenkov, stinger missile or starting smuggling of Russian goods to open market, as it does not cover the entire theme of this essay:-

\section{A- APICULTURE}

Although bee is keeping for producing honey under domestic conditions since long time yet in the areas where Afghan refugees are camped, this industry is introduced in real and wider sense. The most important aspect in which this industry is effected positively, is the 
bringing of Apis Mellifere i.e., European bee by the Afghan refugees. Before Afghan refugees, only Apis (Indica) Cerena a domestic bee was domesticated which produces less honey than the European ones. The Apis Indica Cerena catch disease very fast due to mite causing heavy losses to the bee keeper. After the emergence of European bee in Pakistan, the local domestic bee is being replaced by its fast rate of death, distribution of the European bee by the foreign agencies in Afghan refugees and local imports from Australia. European bee is disease fighter, strong, hardworking and producing much more honey than the local domestic bee. Before the Afghan migration to Pakistan, the local farmers were hesitating in domesticating the bee. They born zeal and interest in the local farmers for keeping it.

\section{B- DOMESTIC ENERGY SAVING}

1. Cook Stove: wood and cowdung have been the primary source of energy for cooking, heating and other basic energy needs since prehistoric time. After the arrival of the refugees to Pakistan from Afghanistan, the demand for commercial energy and non-commercial energy resources i.e., firewood, charcoal and cowdung etc. grew up. The total primary energy consumption of Pakistan is nearly $30 \mathrm{~m}$ tons, of which nearly two-third is met from commercial energy resources while the balance is met from the so-called non-commercial energy resources.

As far as, the need of commercial energy resources for Afghan refugees, is concerned it is assisted by the oil reached monarchs of middle eastern countries while for non-commercial resources, refugees see towards Pakistani forests and cowdung. Pakistan has forests at less than $5 \%$ of areas. Its depletion rate increased after 1978 due to meeting three million refugees non-commercial requirements.

For arresting desertification and depletion of forest ruthlessly, the foreign governments and agencies channelized generous assistance to Pakistan in controlling the situation by growing forests through increasing areas with available improved species of plants, helping in the cutting of forests on scientific methods and domestic energy conservation schemes. Bellerive Foundation of Switzerland has started the dissemination of improved metal cook stoves, kettles and mud ovens among refugees soon after the refugees arrival, aiming to conserve the energy through its use. In 1984, the Project was handed over to G.T.Z. a German technical assistance Project which is now working under two ways namely Pak-German Fuel Efficient Cook Technology with the collaboration of Pakistan Council of Appropriate Technology and Domestic Energy Saving Project for Afghan Refugees. The Project is aiming to conserve energy via its use. It is said by PGFECT that by 
adopting the technology under dissemination in metal cook stove and mud ovens, (bakeries) a big part of the wood would be saved. It is interesting that the mud cook stoves improved technology has been developed by a Professor of NWFP University of Engineering \& Technology with the financial support of Pakistan Council of Appropriate Technology.

\section{Solar Technology for Cooking}

Under the technology, solar energy is used for cooking. It is an appropriate technology in the areas where sun shines a long part of the year. In winter, the cooking in solar cooker takes longer time. It has some drawbacks with it merit of energy saving as spoon cannot be used in the pot during cooking, baking of bread (chapati) is not possible with the solur cooker and tustes of the cooked items minorally changed. M/s SERVE is engaged in the dissemination of this technology in the refugees camps. It has introduced latest type of Solar Cooker from which the Pak inhabitants can also benefit. In Pakistan, PCAT is doing in the field.

\section{C- CARPET MAKING}

M/s Serving Emergient Relief and Vocational Enterprises (SERVE) started a Project of carpet making for boys of Afghan refugees in 1981. The aim of the project was to train the boys in carpet weaving besides creating an income generation source. Trained teachers/instructors were recruited for this purpose.

After receiving training for a year, the Centre grants them a loom with accessories and five $\mathrm{Kg}$ wool and depute them in different camps to carry on their job independently. The Centre also provides marketing facilities to the carpet making unit owners.

At present the Pakistani carpet has bright international market. Pakistan is earning a huge foreign exchange by exporting carpets to other countries. Although the carpet technology being taught to Afghan boys is acquainted by the experts yet it should be spread in the far-flung ares of Pakistan for uplifting the living standard of poor people. The Afghan boys and Small Industrial Development Board, NWFP can play an important role in this connection, if Export Promotion Bureau provide free market facilities to the Weaver. The project working in Afghan boys is important with another aspect also e.g., to disseminate technology to unemployed boys instead of reserving the profession for ancestral carpet makers. 


\section{D- DOME HOUSING}

The project of dome or Gumbad housing was started by DESP a subsidiary of GTZ in 1987. The aim of the project is to limit the use of timber in the camping areas. In NWFP the forests are depleted at a higher rate and the prices of the cement and steel bars are out of reach of the refugees, hence, the construction of dome houses were thought useful for refugees in camping areas. Besides this, the project was also aiming in assisting some of houses facilities to refugees who were living precarious conditions in tentage camps. The dome is a vaulted roof made from sun baked with no framework. This tradition is developed in Persia and very wide spread in the wood poor regions of North, West and South of Afghanistan. The aim of the project was to build only non timber houses for refugees at self help basis instead of provision of ready made houses for refugees. Only a bakery and a school is the exceptional case.

In fact, in Afghanistan, often the houses are constructed on social solidarity and society help basis. The owner of the site receives help from his relatives and neighbours in shape of labour, material and cash. The DESP in light of the Afghan practice assisted those persons in the construction of their dome houses who could have been requested for assistance apart from feasibility of soil, presence of water and supplying of free labour.

As the content of this essay is not explaining the technology in itself rather only impact of the technology on the host country, hence, it is quite to say that the technology under practice for Afghan refugees in building their houses is feasible in Pakistan as it is one of the wood thrust country of the world having appropriate soil required for dome houses. The technology is not a new one for Pakistani measons. However, the innovation made by the DESP must be benefitted by us.

Binishel storage technology for the construction of godown is another technology of dome kind technology, totally introduced by a foreign agency. In our opinion, with some modification and improvement, this could help in storage building system. At present, the work on binishel storage technology is winded up.

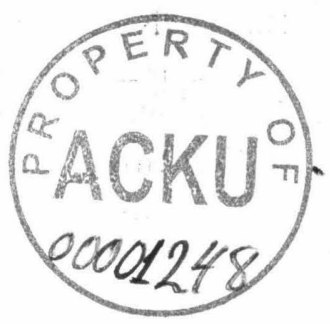


